\title{
Growth efficiency and respiration at different growth rates in glucose-limited chemostats with natural marine bacteria populations
}

\author{
Ramón Cajal-Medrano ${ }^{1}$, Helmut Maske ${ }^{2, *}$ \\ ${ }^{1}$ Facultad de Ciencias Marinas, Universidad Autónoma de Baja California, PO Box 453 Ensenada, CP 22880, \\ Baja California, Mexico \\ ${ }^{2}$ Centro de Investigación Científica y Educación Superior de Ensenada, km 107 carretera Tijuana-Ensenada, Ensenada, \\ Baja California, Mexico
}

\begin{abstract}
Chemostats with glucose-enriched seawater and inoculated with natural populations of heterotrophic marine bacteria were run at different dilution rates $\left(0.05\right.$ to $\left.1.0 \mathrm{~d}^{-1}\right)$, at constant temperature $\left(22^{\circ} \mathrm{C}\right)$ and with low organic substrate medium $(20 \mu \mathrm{M}$ glucose). The following parameters were measured: cell abundance, POC, PON and total $\mathrm{CO}_{2}$ produced. The results demonstrated an increase in growth efficiency with higher specific growth rates within the growth rate range investigated here that is typical for oceanic samples. The results were parameterized according to the Pirt model, with a maximum efficiency of substrate conversion $(\varepsilon=0.57)$ and a specific rate of maintenance metabolism $\left(a=0.41 \mathrm{~d}^{-1}\right)$, although the experimental results within the limited growth rate range investigated here are not statistically different from a linear relationship. On first principals it can be argued that the growth efficiency has to pass through the origin and have a maximum efficiency below 1.0, thus suggesting an asymptotic relationship like the Pirt model. Applying the iterative method of model parameter adjustment to previously published data, similar growth efficiency versus growth rate relationships were arrived at. Our results confirm that at a particular temperature a proportionately higher fraction of dissolved organic material is remineralized in oligotrophic oceans that support lower growth rates than in waters supporting higher growth rates. Consequently, in the latter waters, the efficiency of transfer of dissolved organic material into the particulate form is supposed to be higher.
\end{abstract}

KEY WORDS: Bacterial growth efficiency $\cdot$ Respiration $\cdot$ Chemostats $\cdot$ Glucose

Resale or republication not permitted without written consent of the publisher

\section{INTRODUCTION}

The consumption of dissolved organic carbon by marine bacterioplankton and its conversion into bacterial biomass has been studied within the last 2 decades, showing a great range of values. Several studies tried to explain the wide range $(<0.1$ to $>0.6)$ of the reported bacterial growth efficiency, $Y$ (carbon biomass formed/carbon substrate consumed; see Table 1 for symbols) in the aquatic environment (Cole \& Pace 1995, del Giorgio \& Cole 1998, 2000, Rivkin \& Legendre 2001). It was concluded that $Y>0.5$ is unlikely to occur in bacterial communities growing on natural substrate concentrations, and that in the open ocean values of 0.15 are common (del Giorgio \& Cole 1998, 2000). The magnitude of the bacterial growth efficiency has a profound effect on the marine organic carbon cycle (del Giorgio et al. 1997, Williams 1998, del Giorgio \& Duarte 2002) because it indicates the proportion of the dissolved organic matter (DOM) that is made available by the bacteria as particulate organic matter (POM) to the higher trophic levels. It should be emphasized that the focal point of this work is not the control of the specific growth rate by substrate limitation (cf. Koch 1997), but the relation of the specific growth rate to growth efficiency. 
Table 1 . List of symbols. $B$ : biomass: $t$ : time; $R$ : respiration rate

\begin{tabular}{|c|c|c|}
\hline Symbol & Definition & Units \\
\hline$\mu$ & Specific growth rate $\mu=\frac{d B}{B d t}$ & $\mathrm{~d}^{-1}$ \\
\hline$\varepsilon$ & $\begin{array}{l}\text { Efficiency of substrate biosynthesis } \\
\text { into biomass or into energy equi- } \\
\text { valents for maintenance respration }\end{array}$ & Unitless \\
\hline$a$ & $\begin{array}{l}\text { Specific rate of maintenance } \\
\text { metabolism }\end{array}$ & $\mathrm{d}^{-1}$ \\
\hline$r$ & $\begin{array}{l}\text { Specific respiration rate, } \\
\qquad r=\frac{d R}{B d t}=\frac{d \mathrm{CO}_{2}}{\mathrm{POC}} \times \text { Dilution rate }\end{array}$ & $\mathrm{d}^{-1}$ \\
\hline$Y$ & $\begin{array}{l}\text { Bacterial growth efficiency, } \\
\qquad Y=\frac{d \mathrm{POC}}{d \mathrm{POC}+d \mathrm{CO}_{2}}\end{array}$ & Unitless \\
\hline
\end{tabular}

It is known that bacterial growth efficiency may be affected by environmental factors like temperature (Rivkin \& Legendre 2001, Biddanda \& Cotner 2002), substrate concentration (Pomeroy \& Wiebe 2001) and composition, inorganic nutrients (Kroer 1993), phages (Middelboe et al. 1996) and physiological conditions (Ingraham \& Marr 1996) like cellular synthesis, extracellular polymer formation, excretion of low molecular weight metabolites, maintenance functions and regulatory processes (Neijssel et al. 1996). Evaluation of the published data is made difficult because often methods were used that depend on empirical conversion factors that have been shown to be highly variable, for example the carbon biomass per cell (Vrede et al. 2002).

Empirical models have been used to describe the bacterial growth efficiency as a function of growth rate $(d B / d t)$ (Roland \& Cole 1999) or as a function of specific growth rate $(d B / B d t)$ (Cajal-Medrano \& Maske 1999). The model of Roland \& Cole (1999) describes the bacterial growth efficiency as a function of growth rate by a hyperbolic relationship. If it is assumed that the growth efficiency is a function of bacterial physiology then it should be related to the specific growth rate. On first principles it can be assumed that at zero specific growth rate the growth efficiency is zero and a maximum value below 1.0 is reached at high growth rates; this would suggest an asymptotic relationship as long as the maximum growth efficiency is not reached at intermediate specific growth rates. The Pirt model provides such an asymptotic functional relationship (Cajal-Medrano \& Maske 1999), where the bacterial growth efficiency approaches asymptotically a maximum value $(\varepsilon)$, with increasing growth rate (see Table 1 for symbols). The specific rate of maintenance metabolism $\left(a, d^{-1}\right)$ par- tially defines the shape of the curve. The Pirt model can be conceptualized the following way: The incorporated organic substrate is converted into metabolic energy by respiration or directly converted into biomass. The metabolic energy equivalents are used for biosynthetic processes producing growth and cellular maintenance processes that do not produce new biomass but maintain cell integrity. With decreasing generation times the use of maintenance energy is reduced and thus growth efficiency is increased. The Pirt model parameterizes these cellular functions using the parameter $\varepsilon$, a factor defining the conversion efficiency of the organic substrate to biomass and to energy for maintenance processes. The conversion to biomass includes the substrate directly converted into biomass and the substrate respired to fuel the metabolism for biomass synthesis (Cajal-Medrano \& Maske 1999). The parameter $a$ is the specific rate of the oxidation of organic carbon in order to provide the energy demand for cellular maintenance. The specific rate of respiration that is used for cellular maintenance is then given by $a / \varepsilon$, where $\varepsilon$ defines the efficiency of substrate conversion into cellular energy equivalents. From the model, a relationship between the specific respiration rate and the growth rate $\{r=[\mu$ $(1 / \varepsilon-1)+a / \varepsilon]\}$ can be derived. Previously we calculated the parameter values for $a$ and $\varepsilon$ analytically from this relationship between $r$ and $\mu$ (CajalMedrano \& Maske 1999). In this work we opted to estimate iteratively the parameters directly by minimizing the squared errors between the model and the data using the $Y$ versus $\mu$ relationship, thus avoiding the necessity to first calculate $r$ from $Y$ and $\mu$ and then derive $a$ from the $r$ and $\mu$ relationship (Eq. 13 in CajalMedrano \& Maske 1999).

This model has been used to explain bacterial growth efficiency data reported in the literature (Cajal-Medrano \& Maske 1999) but we did not report data from experiments designed to test the Pirt model. Here we present data from chemostat experiments of marine bacterioplankton growing under carbon limitation. We used natural bacterial populations for the culture inoculum to document the physiological potential of the natural populations, thus allowing for a more general interpretation. To reduce the bias in the data due to the specific taxonomic composition of the population at the time of sampling the inoculum, 2 series of experiments were performed over a period of several years in a range of specific growth rates that we consider typical for natural marine bacterial populations. In both chemostat series the parameters cell abundance, POC, PON, viral abundance and total $\mathrm{CO}_{2}$ produced were measured. In this study we present experimental evidence that the bacterial growth efficiency is a function of specific growth rate. 


\section{MATERIALS AND METHODS}

Culture preparation. Seawater was collected offshore within the California Current on several occasions. To reduce the natural DOC content, the seawater was held in a $200 \mathrm{l}$ polyethylene tank in the dark, treated with $250 \mathrm{~g}$ of activated charcoal and stirred with a filtered $(0.2 \mu \mathrm{m})$ air current. After 5 to $7 \mathrm{~d}$, the activated charcoal was removed by filtration with GF/F filters. Batches of 201 of seawater were prepared using clean glass carboys. Water was aged for 2 to 4 mo and then filtered with $0.2 \mu \mathrm{m}$ polycarbonate filters to remove particles, transferred into a clean glass carboy and stored in the dark for another 2 to 4 mo when filtration was repeated. The total period of aging before use was between 12 and 36 mo. Nutrients were added to $20 \mathrm{l}$ batches in polycarbonate carboys $(20 \mu \mathrm{M}$ glucose, $30 \mu \mathrm{M} \mathrm{NH} \mathrm{Cl}_{4}, 5 \mu \mathrm{M} \mathrm{KH}_{3} \mathrm{PO}_{4}, 0.4 \mu \mathrm{M} \mathrm{FeCl}$ ). Before autoclaving, the seawater $\mathrm{pH}$ was lowered to approximately 6.2 by passing a stream of filtered $\mathrm{CO}_{2}$ (activated charcoal and GF/F filter) for 3 min through the seawater held in a 201 polycarbonate carboy. The seawater medium was autoclaved for $1 \mathrm{~h}$ at 15 psi. After the seawater medium was cooled, the air equilibrium was reestablished by bubbling with $0.2 \mu \mathrm{m}$ filtered air. The final $\mathrm{pH}$ of the sterile medium was around 8.3. The seawater medium such prepared showed no or very little visual precipitation.

Continuous culture system. All the tubing, bottles and stoppers of the culture system were either Teflon or silicon, except for the media reservoir. The seawater medium was kept sterile in 201 polycarbonate carboy (Fig. 1, \#1) with a silicon stopper. The sterility of the medium was regularly tested by passing a small volume of it into a ZoBell-enriched culture vessel (\#6). Media samples were drawn in a sterile fashion, using a bypass (\#12, \#13). The pump rate was controlled by a valveless revolving piston pump (\#18) (Fluid Metering Inc.) on the outflow side of the culture, delivering the outflow into a formaldehyde sterilized container (\#19). Bacteria were cultured in the dark in 1 or 21 Teflon (PTFE) bottles with silicon stoppers (\#20) with minimum air head (shaded area), and continuously agitated at $140 \mathrm{rpm}$ using a glass-coated magnetic stirrer (\#21) at constant temperature $\left(22^{\circ} \mathrm{C}\right)$. The samples presented here were drawn during steady state directly from the culture volume (\#23), admitting sterile filtered air (\#16) into the culture vessel and thus terminating the steady state.
The chemostat experiments were run in 2 different series of experiments with a similar range of dilution rates; in the first series (January to June 1999), 5 different dilution rates were run, and in the second series (July to October 2002), 7 different dilution rates. Both series of chemostats were inoculated with natural bacterial assemblages from surface samples (Pacific coast, $\left.32^{\circ} \mathrm{N}, 116.5^{\circ} \mathrm{W}\right)$. The inoculum was prefiltered through GF/F (Whatman) and then through a polycarbonate filter of $0.6 \mu \mathrm{m}$ (Nucleopore). The empty chemostat vessel was started with $2 \mathrm{ml}$ inoculum; the vessel was slowly filled and then, after more than $1 \mathrm{~d}$, pumping was started at the desired rate. For each new steady state experiment a new inoculum was used. The steady state of the chemostat culture was determined by bacterial cell counts obtained from the outflow. The cell abundance was initially checked once a day and then more frequently before steady state sampling. Bacterial abundance at steady state was little above natural concentrations, ranging in the different chemostats from $3.7 \times 10^{5}$ to $1.5 \times 10^{7}$ cells ml ${ }^{-1}$. Steady state was defined by less than $20 \%$ variation between samples for approximately $2 \mathrm{~d}$. The steady state was

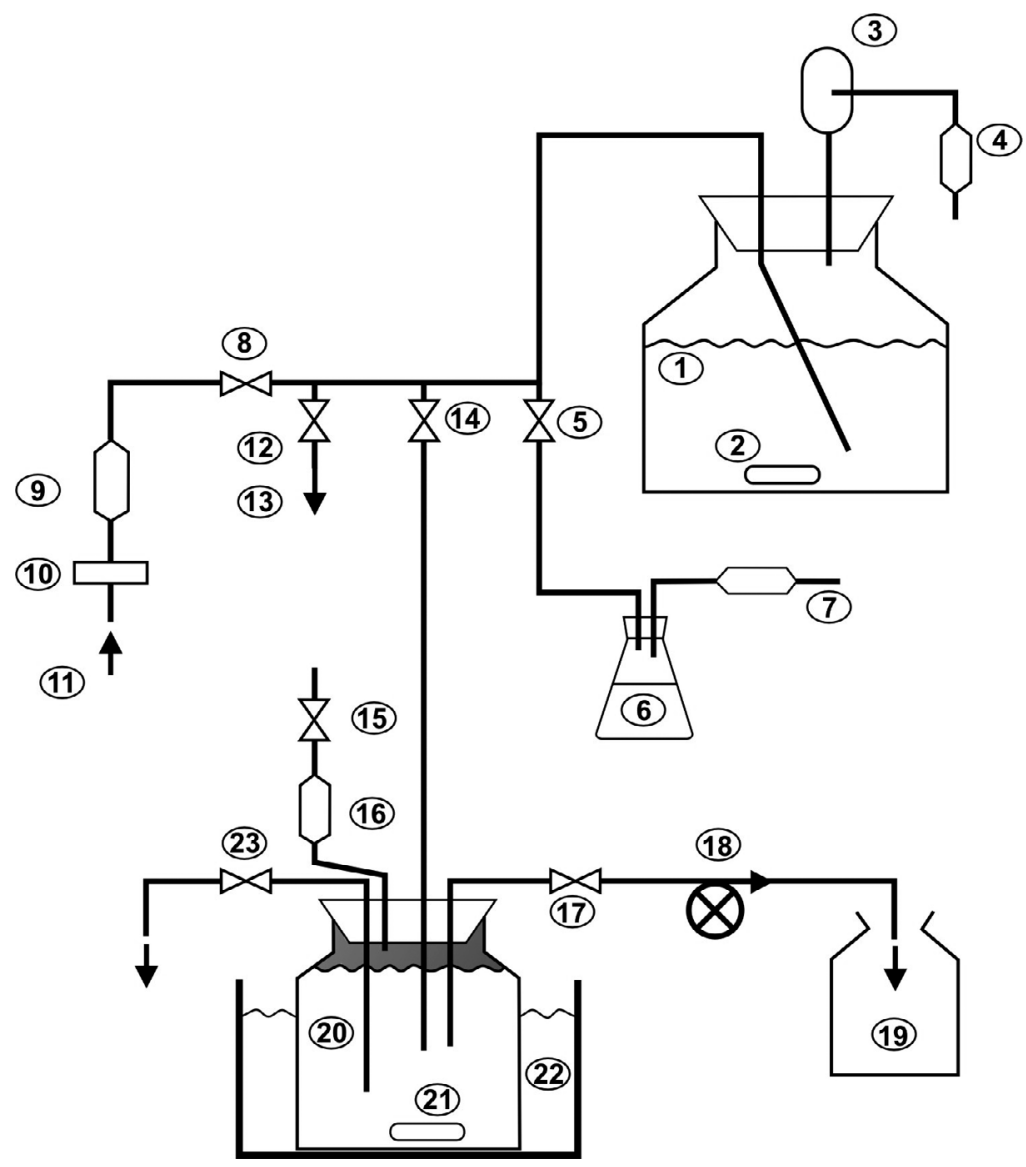

Fig. 1. Components of the chemostat culture system. See 'Materials and methods' for description of the different components 
reached after 3.5 and $19 \mathrm{~d}$; there was no relation between the dilution rate and the time needed to reach steady state.

Bacterial abundance. Bacterial abundance was determined by counts of DAPI-stained (Molecular Probes) bacteria in filtered samples that were preserved immediately after collection on $0.2 \mu \mathrm{m}$ black polycarbonate filters (Poretics) following Turley \& Hughes (1992). In each sample, 32 fields with a total of 350 to 1200 cells (Kirchman 1993) were counted with an epifluorescence microscope (Jena Lumar).

Virus-like particles (VLPs). VLPs were counted using an epifluorescence microscope (Zeiss Axiovert) after filtration onto $0.02 \mu \mathrm{m}$ aluminum oxide filters (Anodisc, Whatman), using Yo-Pro-1 (Molecular Probes) for the first series of chemostats and SYBRGreen I (Molecular Probes) for the second series according to Hennes \& Suttle (1995) and Noble \& Fuhrman (1998), respectively.

Particulate organic carbon and nitrogen. Duplicate samples from the culture and media were obtained at the end of the steady state by filtering a volume of 140 to $430 \mathrm{ml}$ onto precombusted $\left(450^{\circ} \mathrm{C}\right.$, $2 \mathrm{~h})$ glass fiber filters (GF/F, Whatman) using precombusted filter holders. Combusted GF/F filters are expected to retain all bacteria due to their reduced pore size after combustion (Nayar \& Chou 2003). Filters were frozen at $-40^{\circ} \mathrm{C}$ and for the second series the samples were lyophilized before analysis with a CHN analyzer (Marine Science Institute, University of California, Santa Barbara). Duplicate CHN blanks were obtained both from the unused combusted filters and by filtering 350 to $400 \mathrm{ml}$ of growth medium. The POC produced in culture (dPOC), was calculated as:

$$
\begin{aligned}
d \mathrm{POC}= & \left(\mathrm{POC}_{\mathrm{c}}-B\right) / V_{\mathrm{c}} \\
& -\left(\mathrm{POC}_{\mathrm{m} 1}+\mathrm{POC}_{\mathrm{m} 2}-2 \mathrm{~B}\right) /\left(V_{\mathrm{m} 1}+V_{\mathrm{m} 2}\right)
\end{aligned}
$$

The subscripts $\mathrm{c}, \mathrm{m} 1$ and $\mathrm{m} 2$ refer to the culture and media samples, respectively, $B$ is the empty filter blank and $V$ the filtered sample volumes. We estimated the standard deviation of the POC produced in culture as follows: using duplicate measurements, we calculated for each duplicate of culture and media samples a standard deviation correcting the estimate with a factor 1.25 (Gurland \& Tripathi 1971) to account for the low sample number, resulting in $\sigma_{\text {poc }}=3.06 \mu \mathrm{M} \mathrm{C}$. From the individual estimates of standard deviation we took the median value as a representative standard deviation for the POC measurement. The standard deviation of the POC produced in culture $\left(\sigma_{\text {cul }}\right)$ was calculated by error propagation using the representative standard deviation of single measurements, $\left[\sigma_{\mathrm{cul}}=\left(2 \sigma_{\mathrm{poc}}{ }^{2}\right)^{-2}\right]$, yielding $\sigma_{\text {cul }}=4.33 \mu \mathrm{M} \mathrm{C}$.
Respiration measurement. Total $\mathrm{CO}_{2}$ was measured by an automatic differential titration technique using a syringe pump (Kloehn 50300) and a pH meter (Orion 701A) similar to that of Hernandez-Ayon et al. (1999). The titration is performed automatically with the aid of a PC controlling the syringe pump and storing the digitized $\mathrm{pH}$ data. The water jacketed titration cell (30.733 ml) was rinsed more than 3 times with tap water, once with distilled water and once with the sample, then filled and kept at constant temperature $\left(25^{\circ} \mathrm{C}\right)$ during the titration. Two inflexion points are obtained from the first derivative of the titration curve. Total $\mathrm{CO}_{2}$ is obtained from the amount of the $\mathrm{HCl}$ consumed between the 2 inflexion points (Hernandez-Ayon et al. 1999). Alternatively the total $\mathrm{CO}_{2}$ can be calculated from $\mathrm{pH}$, total alkalinity and salinity obtained during the titration using the program of Lewis \& Wallace (1998). The precision obtained with our differential titration of the $\mathrm{CO}_{2}$ is in the range of 0.15 to $0.4 \%(\mathrm{CV})$, or 3 to $8 \mu \mathrm{mol} \mathrm{CO}_{2} \mathrm{~kg}^{-1}$, similar to that obtained with columetric techniques. The inorganic carbon produced by respiration was calculated from the difference of the total $\mathrm{CO}_{2}$ content in the culture vessel at steady state and the total $\mathrm{CO}_{2}$ of the medium in the reservoir, both measured in duplicate (data not shown). The standard deviation of the $\mathrm{CO}_{2}$ produced $\left(\sigma_{\text {res }}\right)$ was calculated analogous to POC by first calculating the individual standard deviation of replicates and then using error propagation $\left(\sigma_{\text {res }}=8.75 \mu \mathrm{M} \mathrm{C}\right)$.

\section{RESULTS}

In both series of experiments the POC produced in the chemostat cultures ranged from 20.35 to $153.87 \mu \mathrm{M}$ $\mathrm{C}$ (Table 2). The bacterial $\mathrm{C} / \mathrm{N}$ ratio showed no signifi-

Table 2. Steady-state dilution rate and growth efficiency $(Y)$ in chemostat cultures, particulate organic carbon $(d \mathrm{POC}$, see text for calculation) and carbon dioxide produced

\begin{tabular}{|lrrc|}
\hline $\begin{array}{l}\text { Dilution rate } \\
\left(\mathrm{d}^{-1}\right)\end{array}$ & $\begin{array}{r}d \mathrm{POC} \\
(\mu \mathrm{M} \mathrm{C})\end{array}$ & $\begin{array}{r}d \mathrm{CO}_{2} \\
(\mu \mathrm{M} \mathrm{C})\end{array}$ & $Y$ \\
\hline 0.05 & 43.49 & 242.83 & 0.15 \\
0.114 & 76.43 & 383.23 & 0.17 \\
0.22 & 23.86 & 129.12 & 0.16 \\
0.3 & 153.87 & 323.65 & 0.32 \\
0.3 & 50.30 & 372.35 & 0.12 \\
0.33 & 65.61 & 142.44 & 0.32 \\
0.35 & 20.35 & 116.85 & 0.15 \\
0.5 & 40.99 & 83.03 & 0.33 \\
0.54 & 50.50 & 108.86 & 0.32 \\
0.6 & 31.24 & 60.10 & 0.34 \\
0.7 & 76.48 & 81.24 & 0.48 \\
0.9 & 25.48 & 52.80 & 0.33 \\
\hline
\end{tabular}


cant change with substrate limited specific growth rate in both experiments, falling within a range of 3 to 7 and a mean value of 4.6. These values are within the range of $\mathrm{C} / \mathrm{N}$ ratios observed for marine bacteria (Kirchman 2000). When the cellular $\mathrm{C} / \mathrm{N}$ ratio was plotted against the bacterial growth efficiency again no trend was observed (data not shown). The values of carbon per cell (data not shown) showed no relationship with growth rate; the mode of the values was $60 \mathrm{fg} \mathrm{C} \mathrm{cell}^{-1}$, within the range reported for marine populations (Vrede et al. 2002). The virus/bacteria ratio in the experiments was very low in general and varied between 0.19 and 1.22 (VLPs/bacteria) over the growth rate range without showing a clear tendency.

When the $\mathrm{CO}_{2}$ production $\left(d \mathrm{CO}_{2} d t^{-1}\right)$ is normalized to bacterial biomass production ( $d$ POC $d t^{-1}$ ) an exponential decrease with specific growth rate is observed, showing little change in the ratio at higher growth rates (Fig. 2). When the $\mathrm{CO}_{2}$ produced is recalculated to express specific respiration rate (Table 1 of present study and Eq. 13 in Cajal-Medrano \& Maske 1999) and plotted against growth rate, no significant trend is observed (Fig. 3), although the Pirt model would expect a small increase in specific respiration with growth rate (cf. Eq. 12 in Cajal-Medrano \& Maske 1999); note that the intercept on the ordinate in Fig. 3 is given by $a / \varepsilon\left(\mathrm{d}^{-1}\right.$, see below).

Bacterial growth efficiency $(Y)$ increased asymptotically with dilution rate as shown in Fig. 4. Minimum growth efficiency values in the range of 0.08 to 0.20 are observed at low growth rates $\left(0.05\right.$ to $\left.0.25 \mathrm{~d}^{-1}\right)$ and higher growth efficiency values at higher growth rates

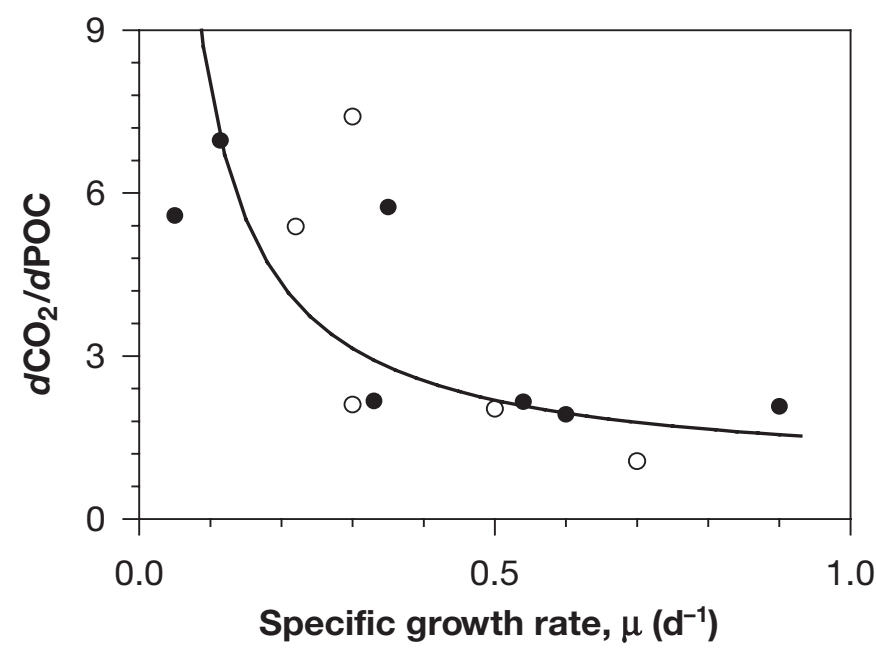

Fig. 2. Ratio of the total $\mathrm{CO}_{2}$ to biomass formed at different growth rates. $\mathrm{O}$, $\bullet$ : data from the first and second series of experiments, respectively. Continuous line is not a best fit to the data in this graph but was calculated using the model parameters obtained from our data to calculate $Y$ and the relationship $d \mathrm{CO}_{2} / d \mathrm{POC}=-1+Y^{-1}$ (see text)

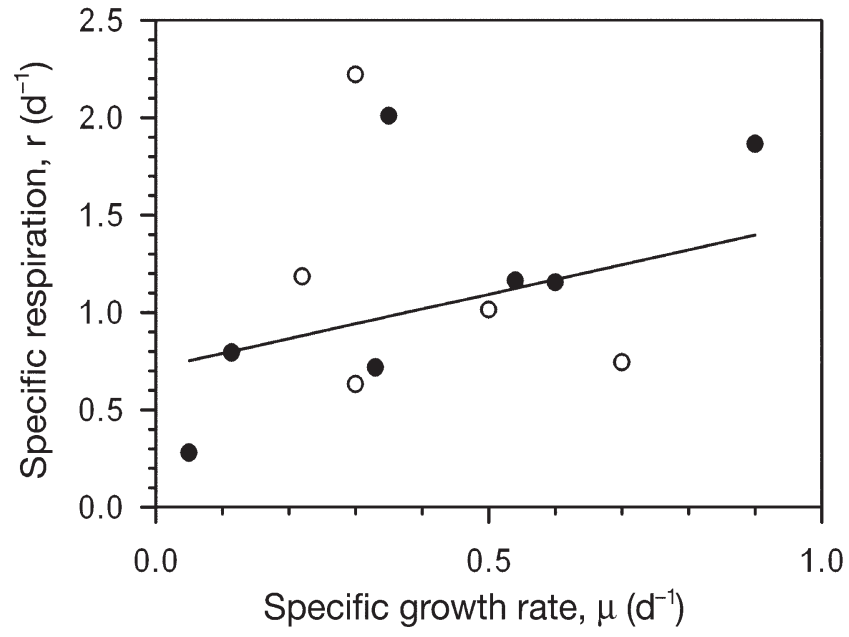

Fig. 3. Specific respiration rate and specific growth rate. $\bigcirc$, data from the first and second series of experiments, respectively. Continuous line is not fitted to the data but calculated according to $r=[\mu(1 / \varepsilon-1)+a / \varepsilon]$ (Cajal-Medrano \& Maske 1999) using the parameters obtained from our data (see text)

$\left(0.6\right.$ to $\left.0.9 \mathrm{~d}^{-1}\right)$. From the data the maximum efficiency of substrate conversion into biomass $(\varepsilon)$ and the specific rate of maintenance metabolism $\left(a, \mathrm{~d}^{-1}\right)$ were calculated (Eq. 11 in Cajal-Medrano \& Maske 1999) using

$$
Y=\mu\left(\mu \varepsilon^{-1}+a \varepsilon^{-1}\right)^{-1}
$$

Parameter values were iteratively adjusted to the data (Table 2) using the Levenberg-Marquardt algorithm (MatLab, v. 6.5) with the least square error cri-

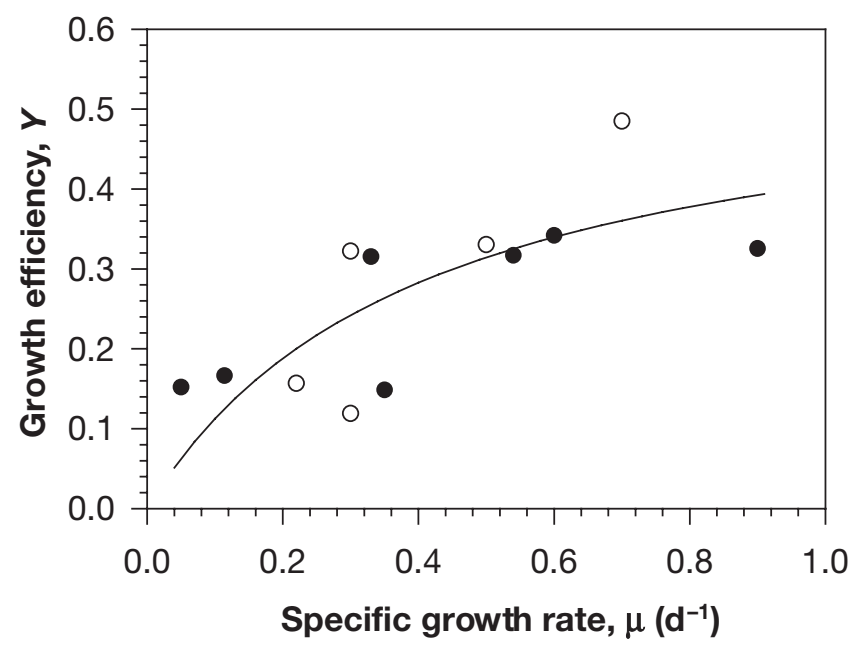

Fig. 4. Bacterial growth efficiency $(Y)$ and specific growth rate $\left(\mu, \mathrm{d}^{-1}\right)$. Continuous line was calculated according to Eq. (1) using the fitted parameter values $\varepsilon=0.57, a=0.41 \mathrm{~d}^{-1}$ $\left(\mathrm{r}^{2}=0.5\right)$. O: first series of experiments; 0 : second series of experiments 
teria, yielding values with $95 \%$ confidence limits of $\varepsilon=0.57 \pm 0.46$ and $a\left(d^{-1}\right)=0.41 \pm 0.72$. The model fit yielded a coefficient of determination $r^{2}=0.50$. The residuals between modeled and measured data are shown to be symmetrically distributed around zero and without an obvious tendency over the modeled growth efficiency investigated, confirming the Levenberg-Marquardt results. The residuals of the 2 different series of experiments (taken several years apart), are evenly distributed, suggesting that there was no systematic change in results. We also calculated a linear regression $Y$ versus $\mu$ for the same data and arrived at a $Y=0.33 \mu+0.13\left(\mathrm{r}^{2}=0.53\right)$. Although the coefficient of determination of the linear regression is slightly larger than the adjusted Pirt model, we consider the latter to be the more appropriate representation because the growth efficiency should pass through the origin and have a maximum efficiency below 1.0 at high growth rates, thus suggesting an asymptotic relationship like the Pirt model. One reason for the better fit of the linear model might be the limited range of growth rates investigated here that does not include high growth rates with maximum $Y$.

\section{DISCUSSION}

The wide variability of the bacterial growth efficiency values reported (del Giorgio \& Cole 2000) reflect a complex interplay between physiology and the environment with documented environmental control by limitation of organic and inorganic substrate (Pirt 1982, Zweifel et al. 1993), substrate $\mathrm{C} / \mathrm{N}$ ratio (Goldman \& Dennet 1991), temperature (Felip et al. 1996, Sherr \& Sherr 1996, Pomeroy \& Wiebe 2001), organic substrate composition (Vallino et al. 1996) and viral infections (Middelboe et al. 1996). From the physiological point of view there are a number of known conditions that may alter the bacterioplankton growth efficiency, i.e. cellular synthesis, extracellular polymer formation, low molecular weight metabolites, maintenance functions, regulatory processes (Neijssel et al. 1996), the uncoupling between catabolism and anabolism (del Giorgio \& Cole 2000) and cellular lysis. The ratio of VLPs to bacteria in our cultures was between 0.2 and 1.2, a low ratio compared to natural samples (5 to 25) (Fuhrman 1999, Paul \& Kellogg 2000), suggesting low lytic activity by bacteriophages in our continuous cultures and hence little influence of lysis on the quantitative outcome of the experiments.

There are no published data of the relationship between bacterial growth efficiency and the specific growth rate for natural populations in culture within the interval of specific growth rates reported for the ocean and organic substrate concentrations that are close to natural. The growth rate range of our experiments $\left(0.05\right.$ to $\left.1.0 \mathrm{~d}^{-1}\right)$ is similar to that reported as representative for oceanic natural bacteria (Ducklow 1983, Ducklow \& Carlson 1992). Other studies have shown a positive relationship between the bacterial production $(d B / d t)$ and bacterial growth efficiency (del Giorgio \& Cole 1998, Roland \& Cole 1999) in bacterioplankton from estuarine areas; in addition a proportionality between bacterial growth efficiency and specific growth rate has been found in bacteria attached to macroscopic organic aggregates of riverine zones (Grossart \& Ploug 2000), but these studies have not used quantitative models to interpret their data.

The Pirt model parameter values from this study $(\varepsilon=$ $0.57, a=0.41 \mathrm{~d}^{-1}$ ) are different from the parameter values obtained by us in a previous study of compiled literature data with growth rates below $4 \mathrm{~d}^{-1}(\varepsilon=0.51$ and $a=0.58 \mathrm{~d}^{-1}$ ) (Fig. 6 in Cajal-Medrano \& Maske 1999). Part of the difference is expected to be due to different methods and range of specific growth rates. Also, in the former publication, we used an analytical method to derive $a$ and $\varepsilon$ based on the linear regression between specific respiration and specific growth rate, whereas here we used the iterative Levenberg-Marquardt algorithm which minimizes the squared difference between the Pirt model and the data of growth efficiency and specific growth rate (Fig. 4). Both approaches are based on minimizing the squared differences between model and data, but they lead to different parameter estimates because the analytical method is based on the data transformation to specific respiration. We choose here to apply the iterative method to work with the principle data product (growth efficiency) and not a derived variable (specific respiration). When the iterative method was applied to the literature data $\left(\mu<1 \mathrm{~d}^{-1}\right.$, Cajal-Medrano \& Maske 1999), the parameter values differed considerably from those estimated for our experimental data $(\varepsilon=0.47$ and $a=0.23 \mathrm{~d}^{-1}$ ), but visually the $Y$ versus $\mu$ relationship within the experimental range of growth rate was similar (Fig. 5).

We propose that the noise in our data (Fig. 4) and in the literature values are partially due to differences in the taxonomic composition of the assemblages in our cultures. A possible explanation for the deviation of data from the Pirt model might be the formation of quiescent states at low growth rates under conditions of starvation. The quiescent states might control the specific rate of cellular maintenance energy demand, $a$, which is assumed to be constant over all growth rates in the Pirt model. Future work should elucidate the importance of the metabolic state changes and of the taxonomic composition on the physiological potential of the community. 


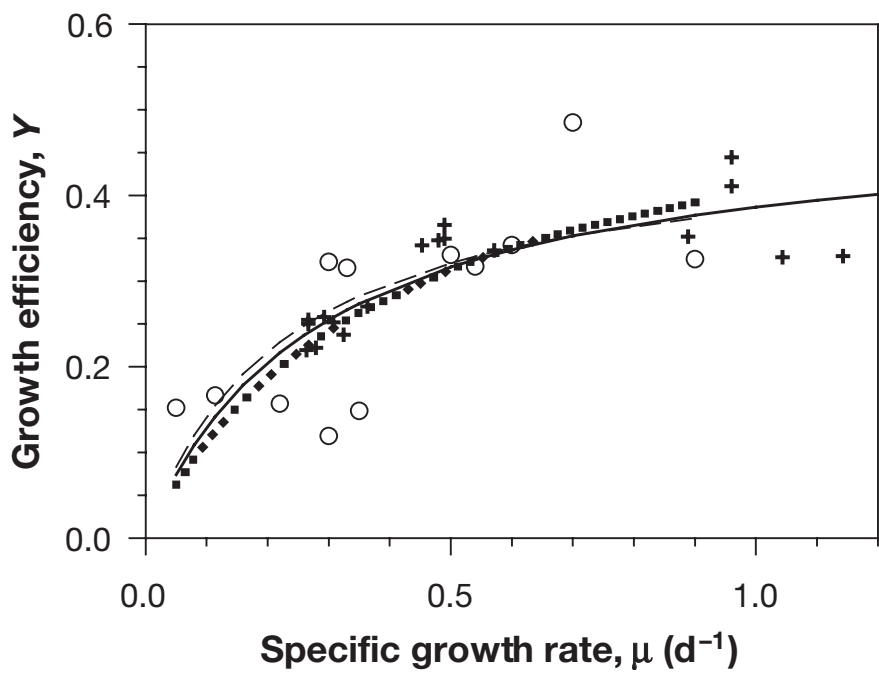

Fig. 5. Growth efficiency versus specific growth rate from our chemostat data (O), data published by Middelboe et al. (1992) (+). Continuous line represents the model result based on the data by Middelboe et al. (1992) and our data $(a=0.28, \varepsilon=$ $0.503, r^{2}=0.59$ ). For comparison, model results are included, based on our data (Fig. 4) (dotted line) and literature data below a growth rate of $1.0 \mathrm{~d}^{-1}$ (Cajal-Medrano \& Maske 1999) using the iterative parameter estimate (LevenbergMarquardt) (dashed line)

In Fig. 2, the ratio of the change in total $\mathrm{CO}_{2}$ to biomass formed at different growth rates is shown. These data would be similar to what one would observe in a closed system, for example if no gas exchange would take place as in a stratified water column. At specific growth rates above $0.5 \mathrm{~d}^{-1}$, little change in the ratio would be observed, but at lower specific growth rates the ratio would increase strongly. The continuous line was calculated from $d \mathrm{CO}_{2} / d \mathrm{POC}=-1+Y^{-1}$, using the model parameters to calculate $Y$. The results of specific respiration (Fig. 3) versus growth rate show a very different pattern; no significant increase with growth rate is observed and only a small increase would be expected within the growth rate interval according to the Pirt model (Fig. 3). The Pirt model is structured such that the maintenance metabolism $\left(a / \varepsilon=0.71 \mathrm{~d}^{-1}\right)$ is assumed to be constant, equal to the intercept in Fig. 3. It could be argued that maintenance metabolism or maintenance respiration a should be a function of growth rate, but this discussion would be outside the scope of this work (see comments in Koch 1997). Thingstad (1987) explored the possibility to parameterize independently the efficiency to convert the organic substrate into bacterial biomass and the efficiency to support the maintenance metabolism, whereas here we used one single parameter set $(a / \varepsilon)$ to define both efficiencies. Thingstad's assumption has not been supported by experimental data so far; future efforts should try to separate the efficiencies of biomass con- version and maintenance respiration at different growth rates and with different types of energy substrates.

It is noteworthy that the $\mathrm{C} / \mathrm{N}$ ratio did not change with growth rate or growth efficiency. Thus the pattern explained by the Pirt model would not change if the biomass would be parameterized as protein. In addition, the trophic quality of biomass transferred to higher trophic levels is not expected to differ for a given temperature at different growth rates, i.e. in high or low substrate waters.

A comparison of our data with other published data that use oxygen respiration measurements for growth yield estimates is made difficult by the need to use respiratory quotient conversion factors (Robinson \& Williams 1993), as long as no information on the relation of RQ to specific growth rate is available. There are few published data based on a methodology similar to our experiments and performed at similar temperatures. For example, Middelboe et al. (1992) used chemostats at $18^{\circ} \mathrm{C}$ inoculated with natural populations and natural substrate. They used cell counts converted into bacterial carbon and DIC (dissolved inorganic carbon) determination for $\mathrm{CO}_{2}$ production. Their relationship of the growth efficiency versus specific growth rate is well described by our model and when plotted together with our data there is a reasonable overlap (Fig. 5). For the combined set of Middelboe et al. (1992) and our data the Levenberg-Marquardt routine yielded $a=0.28 \mathrm{~d}^{-1}$ and $\varepsilon=0.50$ with $\mathrm{r}^{2}=0.59$. We also recalculated the model parameters $\mu<1.0 \mathrm{~d}^{-1}$ from literature data (Cajal-Medrano \& Maske 1999) using the iterative method and arrived at values of $a=$ $0.23 \mathrm{~d}^{-1}$ and $\varepsilon=0.47$ with $\mathrm{r}^{2}=0.46$. Although the parameter values for the 3 data sets differed significantly, the model curves of these 3 sets of parameter values yielded curves that were visually similar within the growth rate range investigated here (Fig. 5).

In our experiments, glucose was added as an organic substrate, with the expectation that most coastal marine bacteria would be able to metabolize it. Middelboe et al. (1992) did not add organics to their cultures but used natural brackish water instead. The similarity of results suggests that glucose was a suitable substrate compound to experimentally explore the relationship between specific growth rate and growth efficiency in taxonomically diverse natural populations.

\section{Consequences for ecological interpretations}

Our chemostats provided us with an estimate of the specific growth rate $\left(\mu, \mathrm{d}^{-1}\right)$ of the bacterial community which is essential to understand the regulation of bac- 
terial production in aquatic environments (Ducklow 2000, Kirchman 2002). We realize that within natural samples, bacteria coexist with very different physiological potential and very different specific growth rates, but the specific community growth rate still represents the relevant response of the community to environmental conditions. In our experiments we only investigated the effect of organic substrate limitation at one temperature, but organic substrate limitation is arguably the most important limiting factor for bacterial specific growth rate in the ocean (see Table 4 in Williams 2000). If we consider our results and the concept of the Pirt model in the oceanic context it is expected that the growth efficiency varies greatly in oceanic waters because it is exactly at the lower growth rates typical for oceanic waters that the $Y$ changes strongly with growth rate. In oligotrophic areas with low growth rates, a relatively higher proportion of the dissolved organic matter will be respired compared to eutrophic (coastal) areas of the same temperature range, i.e. the efficiency of transfer of dissolved to particulate matter is higher in coastal areas and the remineralization is higher in offshore, more oligotrophic areas. This pattern corresponds with the lower $f$-ratio (new primary production to the sum of regenerated and new primary production) in low inorganic nutrient waters where more locally recycled nitrogen is consumed by primary producers, because according to our interpretation more recycled nitrogen would be made available due to the higher mineralization of dissolved organic matter. The latter would be driven by the low growth rate of bacteria controlled by the lower dissolved organic concentration. The growth efficiency of the bacteria should also be a key element determining the size distribution of metabolic activity. At low growth efficiency more dissolved organic matter will be remineralized, keeping the nutrients cycling within the microbial cycle; at high growth efficiency the organic material is transferred from the dissolved phase into the particulate phase and with increased probability into the larger trophic size fractions. A quantifiable relationship between the specific growth rate and growth yield could thus link 2 very important parameters for future modeling efforts.

The above argument should be applied with caution because a covariation of the more oligotrophic oceanic regions with higher temperatures is expected, and because the effect of temperature on the interdependence of specific growth rate and growth efficiency is not known. Therefore a recent report (Rivkin \& Legendre 2001) showing a decrease in growth efficiency with higher temperature is difficult to evaluate, specially because no information on the specific growth rate is included and because substrate limitation might have biased the temperature effect (Felip et al. 1996, Pomeroy \& Wiebe 2001). In recent experiments performed in our laboratory (data in preparation) the cultures without substrate limitation at maximum growth rates showed increasing growth efficiency with temperature.

There are potential caveats accompanying the application of the Pirt model to natural samples where a range of different growth rates can occur within one small volume. For example, bacteria associated to particles are supposed to grow faster than bacteria of the same sample that are growing freely (Azam 1998, Azam \& Long 2001). This has consequences that need to be explored further because the non-linear relationship between $\mu$ and $Y$ makes it difficult to quantitatively interpret the whole assemblage as one physiological entity, although this complication would not alter the tendency of increasing growth efficiency with higher specific growth rate.

Acknowledgements. This work was supported by the grants CONACYT 3588-T and UABC-CICESE 0247.

\section{LITERATURE CITED}

Azam F (1998) Microbial control of oceanic carbon flux: the plot thickens. Science 280:694-696

Azam F, Long R (2001) Sea snow microcosms. Nature 414: 495-498

Biddanda BA, Cotner JB (2002) Love handles in aquatic ecosystems: the role of dissolved organic carbon drawdown, resuspended sediments, and terrigenous inputs in the carbon balance of Lake Michigan. Ecosystems 5: 431-445

Cajal-Medrano R, Maske H (1999) Growth efficiency, growth rate and the remineralization of organic substrate by bacterioplankton - revisiting the Pirt model. Aquat Microb Ecol 19:119-128

Cole JJ, Pace ML (1995) Why measure bacterial production? A reply to the comment by Jahnke and Craven. Limnol Oceanogr 40:441-444

del Giorgio PA, Cole JJ (1998) Bacterioplankton growth efficiency in natural aquatic systems. Annu Rev Ecol Syst 29: 503-541

del Giorgio PA, Cole JJ (2000) Bacterial energetics and growth efficiency. In: Kirchman DL (ed) Microbial ecology of the oceans, Wiley-Liss, New York, p 289-325

del Giorgio PA, Duarte CM (2002) Respiration in the open ocean. Nature 420:379-384

del Giorgio PA, Gasol JM, Mura P, Vaqué D, Duarte CM (1997) Respiration rates in bacteria exceed phytoplankton production in unproductive aquatic systems. Nature 385: 148-151

Ducklow HW (1983) Production and fate of bacteria in the oceans. BioScience 33:494-499

Ducklow HW (2000) Bacterial production and biomass in the oceans In: Kirchman DL (ed) Microbial ecology of the oceans. Wiley-Liss, New York, p 85-120

Ducklow HW, Carlson CA (1992) Oceanic bacterial production. In: Marshall KC (ed) Advances in microbial ecology, Vol 12. Plenum Press, New York, p 113-181 
Felip M, Pace ML, Cole JJ (1996) Regulation of planktonic bacterial growth rates: the effects of temperature and resources. Microb Ecol 31:15-28

Fuhrman JA (1999) Marine viruses and their biogeochemical an ecological effects. Nature 399:541-548

Goldman J, Dennet MR (1991) Ammonium regeneration and carbon utilization by marine bacteria by substrate C:N ratio. Limnol Oceanogr 32:1239-1252

Grossart HP, Ploug H (2000) Bacterial production and growth efficiencies: direct measurements on riverine aggregates. Limnol Oceanogr 45:436-445

Gurland J, Tripathi RC (1971) A simple approximation for unbiased estimation of the standard deviation. Am Stat 25: 30-32

Hennes KP, Suttle CA (1995) Direct counts of viruses in natural waters and laboratory cultures by epifluorescence microscopy. Limnol Oceanogr 40:1050-1055

Hernandez-Ayon MJ, Belli S, Zirino A (1999) pH, alkalinity and total $\mathrm{CO}_{2}$ in coastal seawater by potentiometric titration with a difference derivative readout. Anal Chim Acta 394:101-108

Ingraham J, Marr AG (1996) Effect of temperature, pressure, $\mathrm{pH}$, and osmotic stress on growth. In: Neidhardt FC, Curtiss R III, Ingraham JL, Lin ECC and 6 others (eds) Escherichia coli and Salmonella cellular and molecular biology, 2nd edn. American Society for Microbiology, Washington, DC, p 1570-1578

Kirchman DL (1993) Statistical analysis of direct counts of microbial abundance. In: Kemp PF, Sherr BF, Sherr EB, Cole J (eds) Handbook of methods in aquatic microbial ecology. Lewis Publishers, Boca Raton, FL, p 117-120

Kirchman DL (2000) Uptake and regeneration of inorganic nutrients by marine heterotrophic bacteria. In: Kirchman DL (ed) Microbial ecology of the oceans. Wiley-Liss, New York, p 261-288

Kirchman DL (2002) Calculating microbial growth rates from data on production and standing stocks. Mar Ecol Prog Ser 233:303-306

Koch AL (1997) Microbial physiology and the ecology of slow growth. Microbiol Mol Biol Rev 61:305-318

Kroer N (1993) Bacterial growth efficiency on natural dissolved organic matter. Limnol Oceanogr 38:1282-1290

Lewis E, Wallace D (1998) Program developed for $\mathrm{CO}_{2}$ system calculations ORNL/CDIAC-105. Carbon Dioxide Information Analysis Center, Oak Ridge National Laboratory, US Department of Energy, Oak Ridge, TN

Middelboe M, Nielsen B, Sondergaard M (1992) Bacterial utilization of dissolved organic carbon (DOC) in coastal waters - determination of growth yield. Arch Hydrobiol Beih Ergebn Limnol 37:51-61

Middelboe M, Jorgensen NO, Kroer N (1996) Effects of viruses on nutrient turnover and growth efficiency of non infected marine bacterioplankton. Appl Environ Microbiol 62:1991-1997

Nayar S, Chou LM (2003) Relative efficiencies of different filters in retaining phytoplankton for pigment and productivity studies. Estuar Coast Shelf Sci 58:241-248

Editorial responsibility: Frede Thingstad,

Bergen, Norway
Neijssel OM, Teixeira de Mattos JM, Tempest DW (1996) Growth yield and energy distribution. In: Neidhardt FC, Curtiss R III, Ingraham JL, Lin ECC and 6 others (eds) Escherichia coli and Salmonella cellular and molecular biology, 2nd edn. American Society for Microbiology, Washington, DC, p 1683-1691

Noble RT, Fuhrman JA (1998) Use of SYBR Green I for rapid epifluorescence counts of marine viruses and bacteria. Aquat Microb Ecol 14:113-118

Paul JH, Kellogg CA (2000) Ecology of bacteriophages in nature. In: Hurst CJ (ed) Viral ecology. Academic Press, San Diego, CA, p 211-246

Pirt SJ (1975) Principles of microbe and cell cultivation. John Wiley \& Sons, New York

Pirt SJ (1982) Maintenance energy: a general model for energy limited and energy sufficient growth. Arch Microbiol 133:300-302

Pomeroy LR, Wiebe WJ (2001) Temperature and substrate as interactive limiting factors for marine heterotrophic bacteria. Aquat Microb Ecol 23:187-204

Rivkin RB, Legendre L (2001) Biogenic carbon cycling in the upper ocean: effects of microbial respiration. Science 291: 2398-2400

Robinson C, Williams PJleB (1993) Temperature and Arctic plankton community respiration. J Plankton Res 15: 1035-1051

Roland F, Cole JJ (1999) Regulation of bacterial growth efficiency in a large turbid estuary. Aquat Microb Ecol 20: $31-38$

Sherr EB, Sherr BF (1996) Temporal offset in oceanic production and respiration processes implied by seasonal changes in atmospheric oxygen: the role of heterotrophic microbes. Aquat Microb Ecol 11:91-100

Thingstad FT (1987) Utilization of N, P, and organic C by heterotrophic bacteria. I. Outline of a chemostat theory with a consistent concept of 'maintenance' metabolism. Mar Ecol Prog Series 35:99-109

Turley CM, Hughes D (1992) Effects of storage on direct estimates of bacterial numbers of preserved seawater samples. Deep Sea Res 39:375-394

Vallino JJ, Hopkinson CS, Hobbie JE (1996) Modeling bacterial utilization of dissolved organic matter: optimization replaces Monod growth kinetics. Limnol Oceanogr 41: 1591-1609

Vrede K, Heldal M, Norland S, Bratbak G (2002) Elemental composition $(\mathrm{C}, \mathrm{N}, \mathrm{P})$ and cell volume of exponentially growing and nutrient limited bacterioplankton. Appl Environ Microbiol 68:2965-2971

Williams PJleB (1998) The balance of plankton respiration and photosynthesis in the open oceans. Nature 394:55-57

Williams PJleB (2000) Heterotrophic bacteria and dynamics of dissolved organic material. In: Kirchman DL (ed) Microbial ecology of the oceans. Wiley-Liss, New York, p 153-200

Zweifel UL, Norman B, Hagström Å (1993) Consumption of dissolved organic carbon by marine bacteria and demand for inorganic nutrients. Mar Ecol Prog Ser 101:23-32

Submitted: July 15, 2004; Accepted: October 18, 2004

Proofs received from author: January 26, 2005 